\title{
Geophysical criteria for the separation of productive micaceous veins of the Mariinsky emerald-beryllium deposit (the Middle Urals)
}

\author{
Mikhail Petrovich POPOV ${ }^{1,2^{*}}$, \\ Oleg Petrovich PELESHKO ${ }^{3, * *}$ \\ Evgeniya Anatol'evna BAZHENOVA ${ }^{4, *+*}$, \\ Viktor Sergeevich IVANCHENKO ${ }^{4, * * *}$, \\ Vladimir Vasil'evich BAKHTEREV ${ }^{4},{ }^{* * x+* x}$
}

${ }^{1}$ Ural State Mining University, Ekaterinburg, Russia

2Zavaritsky Institute of Geology and Geochemistry of the Ural Branch of RAS, Ekaterinburg, Russia

${ }^{3} \mathrm{AO}$ Mariinsky rudnik, Asbest, Malysheva, Russia

${ }^{4}$ Institute of Geophysics of the Ural Branch of RAS, Ekaterinburg, Russia

Relevance of the work is the development of new methods for rapid extraction (determination) of ore bodies in the underground mine of the field directly. Measurements were carried out both on specially prepared samples in the form of cubes of the same size, and under conditions of natural occurrence. Purpose of the work is to study the magnetic susceptibility and electrical resistivity of the main host rocks and the ore complex (emerald-bearing glimmerites and quartz-plagioclase veins with beryl) in the most famous Ural emerald-beryllium deposit, the Mariinsky deposit.

Methodology of research. In order to study the magnetic properties of typical rocks and ore bodies of the Mariinsky deposit, the PIMV-M field magnetic susceptibility meter with a measurement range of $1 \cdot 10^{-5} \ldots 1$ SI units was used in the underground mine directly. The relative measurement error does not exceed $\pm 10 \%$ in the range of $10^{-4} \ldots 1 \mathrm{SI}$ units. The measurement was carried out by applying the flat surface of the measuring transducer to the bottomhole wall in a lithologically homogeneous section with subsequent measurement and recording of the obtained value in the field document. To study the electrical resistivity, standard samples in the form of cubes of $24 \times 24 \times 24$ mm were used; their composition was investigated with the help of binocular enhancer MBS-10. The measurements were carried out along three axes since almost all samples have anisotropy. The teraohmmeter E6-13A was used for working.

Results. The data on the magnetic susceptibility and electrical resistance of the main host rocks and the ore complex (emerald-bearing glimmerites and quartz-plagioclase veins with beryl) from the Mariinsky deposit are presented. All data are adjusted with the petrographic characteristics of rocks. Conclusions. Possibility in principle is shown for creating a new express-method for isolating quick micaceous veins in wells and mine faces with the simultaneous measurement of magnetic susceptibility and electrical resistance of rocks during mining operations in an underground mine.

Keywords: The Urals, magnetic susceptibility, electrical resistance, glimmerites, quartz-plagioclase veins, emerald-beryllium deposits, Ural emerald mines.

\section{ntroduction}

Currently, the Government of Russia entrusts executives of the Malyshevsky (Mariinsky) emerald-beryllium deposit with the task to restore beryllium mining in Russia. During mining operations, a very important factor affecting the cost and quantity of the extracted commercial element is the possibility of isolating and sorting out quick micaceous veins carried out directly in the mine face while blasthole drilling. Earlier during the active mode of operation of the Malyshevsky mine group (1950-1990), the enterprise used the photoneutron method for such tasks [1]. The application of this method is associated with certain managerial difficulties (the use of strong radiation sources, the creation of isotopes storages, and the organization of a special control service). Therefore, at the early stage of geological exploration, geophysical methods are promising, operational, and low-cost methods of searching for quick micacious veins and serpentinite contacts [2-4].

According to early literature data [2], the magnetic susceptibility of highly basic rocks of the Emerald-bearing line of the Urals ranges from $25 \ldots 63 \cdot 10^{-5}$ to $2520 \ldots 5040 \cdot 10^{-5}$ SI units, and in some cases up to $12600 \cdot 10^{-5}$ SI units. The increased magnetic properties of ultrabasic rocks are associated with accessory magnetite. Moreover, a considerable heterogeneity of ultrabasic rocks was established according to the magnitude of magnetic susceptibility (Table 1), which is mainly due to their serpentinization, carbonatization, and development of talc. Table 1 shows the magnetic susceptibility values obtained by the authors of the work [2] for rocks typical of the deposit. Unfortunately, the authors did not indicate in their work the way the measurements were made (using samples or under conditions of natural occurrence). However, according to their data, rocks of the basic and acidic composition are mainly non-magnetic; amphibolites, gabbros, granitic rock, and glimmerites are distinguished by reduced magnetic susceptibility.

Additionally, according to literature data [2], the dependence of the specific electrical resistance of ultrabasites on the metamorphism intensity is noted:

- slightly serpentized peridotites $-1210 \ldots 3900 \mathrm{Ohm} \cdot \mathrm{m}$, at an average $1900 \mathrm{Ohm} \cdot \mathrm{m}$;

- serpentinites $-300-960 \mathrm{Ohm} \cdot \mathrm{m}$, at an average $750 \mathrm{Ohm} \cdot \mathrm{m}$;

- serpentinite-talc-carbonate rocks $-16 \ldots 21 \mathrm{Ohm} \cdot \mathrm{m}$, at an average $18 \mathrm{Ohm} \cdot \mathrm{m}$;

- talc-carbonate rocks $-2 \ldots 26 \mathrm{Ohm} \cdot \mathrm{m}$, at an average $10 \mathrm{Ohm} \cdot \mathbf{m}$.

"*t* bazenova_jena@mail.ru

D https://orcid.org/0000-0002-2068-7140

ivanchenko_05@mail.ru

http://orcid.org/0000-0002-1294-6050

ugv@bk.ru

http://orcid.org/0000-0002-1174-1301 
Table 1. Characteristics of magnetic susceptibility $\chi$ of rocks of the Ural emerald mines [2].

Таблица 1. Характеристика магнитной восприимчивости $X$ горных пород Уральской изумрудоносной полосы [2].

\begin{tabular}{lccc}
\hline \multirow{2}{*}{ Rock } & \multicolumn{2}{c}{$\chi \cdot 10^{-5}$ SI units } & Average \\
\cline { 2 - 4 } & Number of determinations & Measurements range & 25 \\
\hline Amphibolites & 3646 & $0 \ldots 302$ & 35 \\
Gabbro & 800 & $0 \ldots 126$ & $21 \ldots 370$ \\
Diorites & 3370 & $0 \ldots 2520$ & 10 \\
Granitic rock & 2375 & $0 \ldots 630$ & 1612 \\
Serpentinites & 1226 & $6 \ldots 10000$ & 831 \\
Dolerines & 555 & $6 \ldots 3126$ & 227 \\
Chlorite rocks & 135 & $6 \ldots 1612$ & $18 \ldots 21$ \\
Apoultrabasite glimmerites & 324 & $9 \ldots 40$ & $23 \ldots 30$ \\
Apodiorite glimmerites & 120 & $12 \ldots 50$ & \\
\hline
\end{tabular}

Micaceous veins are distinguished among the host rocks by high electrical resistance, which is caused by their composition - these are shales, consisting mainly of phlogopite with mica scales oriented along shaliness. According to the data of parametric measurements of samples, the average electrical resistivity is $70000 \mathrm{Ohm} \cdot \mathrm{m}$, which is significantly higher than the electrical resistance of the host rocks [2]. However, the measurement technique is also not specified in the work.

The brief geological structure of the Mariinsky emerald-beryllium deposit

The Ural emerald mines are the world-famous ore region, where the largest deposits of beryllium ores and gems are located in Russia: emerald, alexandrite, and phenakite. Gem-stones mining began in 1831 and do not stop until today. Within the Emerald Mines, the only source of beryl is micaceous veins, which are found in the contact of serpentinites in talc-chlorite rocks.

The Mariinskoe (Malyshevskoye) deposit is included in a group of fields that goes under the general name of the Emerald Mines of the Urals. The ore field is attributed to the deposit which is located in the eastern exocontact zone of the large Aduisky granite massif of the late orogenic type. Granites burst a complex of metamorphic and intrusive rocks, which includes: amphibolites and amphibolite schists, carbon-bearing siliceous schists, serpentinized ultrabasites, serpentinites and dolerines derived from them, diorites, quartz diorites and diorite porphyry (Fig. 1).

The contact of the granite massif with a complex of metamorphic and intrusive rocks has the east dip with $65 \ldots 80^{\circ}$ angle and is complicated by bends with flat areas and broad warps. The Mariinskoe deposit is confined to one of such downwarps. The ore field is localized in the eastern flank of the anticlinal bend. The main ore-controlling and ore-distributing structures at the deposit are spatially connected fault zones and dikes of diorite porphyrites [6]. Fault zones are fixed by highly foliated and broken dolerines (usually with additions of chlorite, actinolite, and phlogopite); there are lenticular bodies of serpentinites, as well as dikes of diorite porphyrites and separate sheet-like bodies of carbonaceous silicious schists. Most ore bodies are concentrated in the fault zones oriented mainly in the near north-south and lateral directions. In the fault zones and adjacent areas, all rocks are subject to tectonical boudinage and profound metasomatic changes - phlogopitization, fluoritization, and development of talc (serpentinites). In addition, the most intensive formation of beryllium mineralization is observed in fault zones. In the vertical sections, schistosity zones often unite and diverge again; wedging out and bulges are often noted. It was also noted that sometimes separate feathering fractures depart from the main fault zones; large ore shoots are formed in the areas of intersection with faults. Fault zones can be tracked along the strike up to $1200 \mathrm{~m}$, their thickness varies from 5 to $70 \mathrm{~m}$. Dykes of diorite porphyry play an important role in the formation of the structure of the ore field of the deposit. Along the strike and the fall of the ore zone, five largest dykes are observed in accordance with it, the length of which reaches $1150 \mathrm{~m}$ with a thickness of 5 to $10 \mathrm{~m}$. Dyke-like bodies are spatially closely associated with the identified large fault zones, and the development of ore-bearing structures occurs precisely here, that is, in the areas of occurrence of dykes that create a profound mechanical heterogeneity of the surrounding formation. The ore zone of the deposit has a southern declination at an angle of $50^{\circ}$. On the strike, it is tracked for $1100 \mathrm{~m}$ (horizon $-30 \mathrm{~m}$ ), and it has been explored to a depth of $360 \ldots 500 \mathrm{~m}$ [6]. The vein assemblage is represented by emerald-bearing micaceous and beryl-bearing quartz-plagioclase veins (Figure 1).

Micaceous ore bodies are the only carriers of beryllium raw materials. They contain an overwhelming (more than 95\%) amount of beryl, which is also characterized by the highest $(13.4 \mathrm{~g} / \mathrm{t})$ content of this component. Micaceous assemblage found in talc schists is characterized by the highest $(16.1 \mathrm{~g} / \mathrm{t})$ content of emerald raw materials. They are quite diverse. This diversity is due to different chemical and mineral composition of protoliths, the duration and polygeneration of metasomatic processes. Among the rocks that have undergone metasomatic processing one can mention apohyperbasite and apodiorite rocks [7], apovulcanite and apocarbonate, apoamphibolite and apogabbroic rocks; according to mineral composition of the central zones: Biotite-plagioclase-phlogopite, quartz-plagioclase-phlogopite, topaz-plagioclase-phlogopite, and chrysoberyl-phenacite-phlogopite [5]. Within the ore zones of known deposits of beryl and emerald, micaceous assemblage is accompanied by small veins of talc-carbonate, quartz-epidote, plagioclase, or fluorite composition filling with open cracks.

Methods of studying the magnetic susceptibility of rocks and objects of study

The study of magnetic susceptibility to differentiate the magnetic properties of natural minerals has been repeatedly used by researchers [8-10]. In order to study the magnetic properties of typical rocks and ore bodies of the Mariinsky deposit, the PIMV-M field magnetic susceptibility meter with a measurement range of $1 \cdot 10^{-5} \ldots 1$ SI units was used in the underground mine directly. Relative measurement error does not exceed $\pm 10 \%$ in the range $\left(10^{-4} \ldots 1\right)$ SI units, in the range $\left(10^{-5} \ldots 10^{-4}\right)$ SI units is not rated. Measurement was carried out at barings in mine workings (layering crossdrifts, dass, ore drifts) at horizons $+15,-30$, $-120 \mathrm{~m}$. The measurement was carried out by applying the flat surface of the measuring transducer to the bottomhole wall in a lithologically homogeneous section with subsequent measurement and recording of the obtained value in the field document. At 


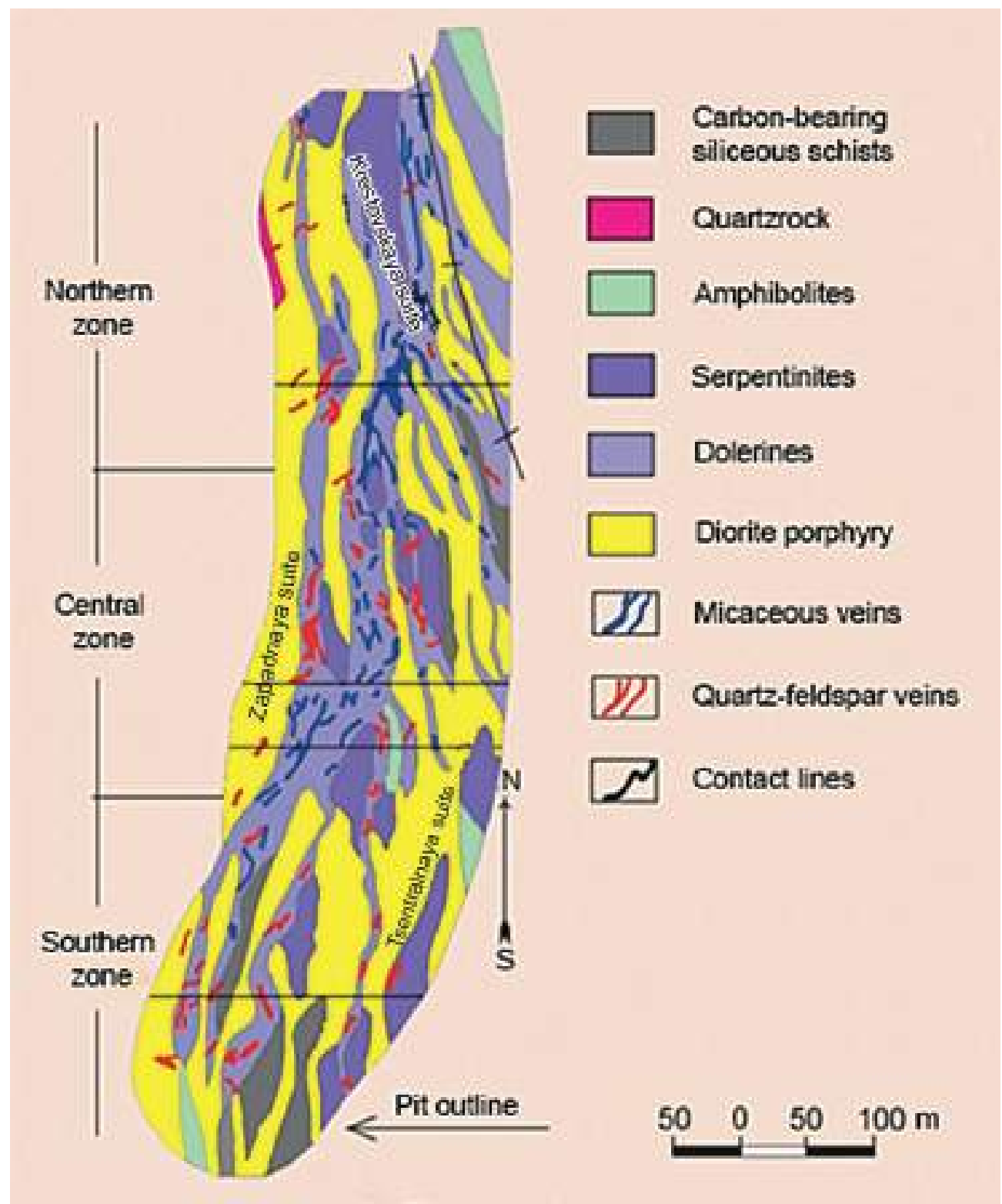

Figure 1. Geological structure of the Mariinsky Deposit [5].

Рисунок 1. Геологическое строение Мариинского месторождения [5].

the same time, the faces under study were uneven (rough), and the gap between the device and the surface under study was from 0.3 to $0.7 \mathrm{~mm}, 0.5 \mathrm{~mm}$ on average. Since the PIVM-M device measures the apparent magnetic susceptibility $k$, the transition to the true magnetic susceptibility value $k$ is realized by the formula $k=k^{\prime} /(1-0.5 k)$. Since all obtained values of apparent magnetic susceptibility are less than 0.1 ( $k^{\prime} \leq 0.1$ SI units), then it was considered to be $k=k^{\prime}[11]$. Due to irregularities of the face walls, i.e. an "outshot-lobe" difference, as a result of which the gap between the measured surface and the flat surface of a transducer is 0.5 $\mathrm{mm}$ on average, the unevenness-correction factor of 1.41 was introduced to calculate the magnetic susceptibility. Table 2 shows the measurement data of magnetic susceptibility in the underground mine.

Methods of studying the electrical resistivity of rocks and objects of study

The electrical resistivity of rocks is carried out both using samples in a laboratory and in natural occurrence. This kind of work has already been done in laboratory setting but with other species of rocks [12,13]. We used standard samples in the form of cubes of size $24 \times 24 \times 24 \mathrm{~mm}$, the composition of which was examined using the binocular enhancer MBS-10 for studying the electrical resistance. The measurements were carried out along three axes since almost all samples have anisotropy. Table 3 shows the average measurement data for different axes. The teraohmmeter E6-13A was used for working. The measurements were carried out according to the method described in [14]. In addition, Table 3 shows the average data of magnetic susceptibility measured along three axes using the same samples in laboratory setting (PIMV-M device).

Discussion of results

The average values of magnetic susceptibility of various rocks and ore complexes of the Mariinsky emerald-beryllium deposit are close (with the exception of serpentinites). The unevenness in magnetization intensity of rocks indicates the connection of their magnetic properties with accessory minerals that are found in them. In serpentinites, magnetite $\mathrm{Fe}_{3} \mathrm{O}_{4}$ (magnetic susceptibility is 4 ... 25 SI units) is most common, and chromite is found. In diorite porphyrites - pyrrhotite $\mathrm{Fe}_{6} \mathrm{O}_{7}$ (magnetic susceptibility 
Table 2. Average data for magnetic susceptibility of the main rocks of the Mariinsky field obtained directly from measurements in an underground mine.

Таблица 2. Средние показатели магнитной восприимчивости основных пород Мариинского месторождения, полученные непосредственно при измерениях в подземном руднике.

\begin{tabular}{|c|c|c|c|}
\hline Names of rocks & Number of measurements & $\begin{array}{l}\text { The average } \chi \text {, } \\
\text { SI units } \cdot 10^{-4}\end{array}$ & $\begin{array}{l}\text { The average, taking into account the coefficient } \\
\qquad 1.41, \mathrm{SI} \text { units }\end{array}$ \\
\hline Serpentinites & 25 & 7.2 & 10.2 \\
\hline Talc schists and rocks & 39 & 3.4 & 4.8 \\
\hline Diorite porphyrite and quartz diorite & 62 & 5.2 & 7.3 \\
\hline Tremolite-actinolite schists & 13 & 3.1 & 4.4 \\
\hline Chlorite schists & 7 & 2.7 & 3.8 \\
\hline Quartz-plagioclase veins & 10 & - & - \\
\hline Micaceous assemblage & 43 & 1.5 & 2.1 \\
\hline Carbon-bearing-siliceous shales & 10 & 5 & 7.1 \\
\hline
\end{tabular}

Table 3. Characteristics of the main host rocks and ore complex of the Mariinsky deposit.

Таблица 3. Характеристики основных вмещающих пород и рудного комплекса Мариинского месторождения.

\begin{tabular}{|c|c|c|c|c|c|c|}
\hline $\begin{array}{l}\text { Sample } \\
\text { number }\end{array}$ & Rock & Texture & Mineral composition & Peculiar properties & $\begin{array}{l}\text { Magnetic } \\
\text { susceptibility, } \\
\text { SI units }\end{array}$ & $\begin{array}{l}\text { Electrical resis- } \\
\text { tivity, MOhm }\end{array}$ \\
\hline $\begin{array}{l}1 \mathrm{~A} \\
1 \mathrm{~B}\end{array}$ & $\begin{array}{l}\text { Quartz-pla- } \\
\text { gioclase }\end{array}$ & Massive & $\begin{array}{l}\text { Quartz - } 80 \% \text {, } \\
\text { plagioclase }-20 \% \text {, } \\
\text { sulfides (less than } 1 \% \text { ) }\end{array}$ & $\begin{array}{l}\text { Sulphide mineraliza- } \\
\text { tion in gray quartz }\end{array}$ & 0 & $\begin{array}{l}900000 \\
900000\end{array}$ \\
\hline $\begin{array}{l}2 \mathrm{~A} \\
2 \mathrm{~B}\end{array}$ & Glimmerite & Schistic & Bastonite & $\begin{array}{l}\text { Occasional } \\
\text { ore inclusions }\end{array}$ & $2.4 \cdot 10^{-4}$ & $\begin{array}{l}200000 \\
320000\end{array}$ \\
\hline $\begin{array}{l}3 \mathrm{~A} \\
3 \mathrm{~B}\end{array}$ & Glimmerite & Massive & $\begin{array}{l}\text { Light-colored micas } \\
\text { sulfides (less than } 1 \% \text { ) }\end{array}$ & $\begin{array}{l}\text { Small sulphides are } \\
\text { distributed } \\
\text { unevenly }\end{array}$ & $4.3 \cdot 10^{-4}$ & $\begin{array}{c}100 \\
95\end{array}$ \\
\hline $\begin{array}{l}4 \mathrm{~A} \\
4 \mathrm{~B}\end{array}$ & Glimmerite & Stratified & $\begin{array}{l}\text { Brown-colored mica - 90\%, } \\
\text { feldspar - } 10 \%\end{array}$ & $\begin{array}{l}\text { Feldspar grains in } \\
\text { glimmerite }\end{array}$ & $2.9 \cdot 10^{-4}$ & $\begin{array}{l}340 \\
180\end{array}$ \\
\hline $\begin{array}{l}5 A \\
5 B\end{array}$ & Serpentinite & $\begin{array}{l}\text { Massive, } \\
\text { eutaxic }\end{array}$ & Serpentine - $90 \%$, talc - $10 \%$ & $\begin{array}{l}\text { Ore mineral is not } \\
\text { visible }\end{array}$ & $1.7 \cdot 10^{-4}$ & $\begin{array}{l}25000 \\
25000\end{array}$ \\
\hline $\begin{array}{l}6 \mathrm{~A} \\
6 \mathrm{~B}\end{array}$ & $\begin{array}{l}\text { Plagioclase } \\
\text { gabbro }\end{array}$ & $\begin{array}{l}\text { Massive, } \\
\text { spotted }\end{array}$ & $\begin{array}{l}\text { Amphibole - } 80 \% \text {, feldspar - } \\
20 \%\end{array}$ & $\begin{array}{l}\text { Ore and sulphide } \\
\text { mineralization is not } \\
\text { detected }\end{array}$ & $1.7 \cdot 10^{-4}$ & $\begin{array}{l}27000 \\
28000\end{array}$ \\
\hline $\begin{array}{l}7 \mathrm{~A} \\
7 \mathrm{~B}\end{array}$ & $\begin{array}{l}\text { Quartz-muscovite } \\
\text { rock }\end{array}$ & $\begin{array}{l}\text { Massive, } \\
\text { eutaxic }\end{array}$ & $\begin{array}{l}\text { Quartz - } 20 \% \text {, light-colored mica - } \\
0 \%, \text { brown-colored mica }-50 \%\end{array}$ & $\begin{array}{l}\text { Rare small, sulphide } \\
\text { mineralization }\end{array}$ & $5.0 \cdot 10^{-5}$ & $\begin{array}{l}900000 \\
450000\end{array}$ \\
\hline $\begin{array}{l}8 \mathrm{~A} \\
8 \mathrm{~B}\end{array}$ & Talc-serpentinite & Knotty & $\begin{array}{l}\text { Serpentine - } 68 \% \text {, } \\
\text { talc }-30 \% \text {, } \\
\text { ore mineral - } 2 \%\end{array}$ & $\begin{array}{l}\text { Pulverous ore inclu- } \\
\text { sion }\end{array}$ & $1.8 \cdot 10^{-4}$ & $\begin{array}{l}400 \\
450\end{array}$ \\
\hline $\begin{array}{l}9 A \\
9 B\end{array}$ & Talc & $\begin{array}{l}\text { Massive, } \\
\text { schistic }\end{array}$ & Talc - $95 \%$, ore mineral $(4-5 \%)$ & $\begin{array}{l}\text { Ore mineral is dis- } \\
\text { tributed evenly along } \\
\text { stratification }\end{array}$ & $6.2 \cdot 10^{-4}$ & $\begin{array}{l}300000 \\
170000\end{array}$ \\
\hline $\begin{array}{l}10 A \\
10 B\end{array}$ & $\begin{array}{l}\text { Phlogopite-pla- } \\
\text { gioclase }\end{array}$ & Knotty & $\begin{array}{l}\text { Plagioclase }-60 \% \text {, brown-col- } \\
\text { ored mica }(40 \%)\end{array}$ & $\begin{array}{l}\text { Mica evaluates } \\
\text { along cracks } \\
\text { in plagioclase vein }\end{array}$ & $5.0 \cdot 10^{-5}$ & $\begin{array}{l}70000 \\
80000\end{array}$ \\
\hline $\begin{array}{l}11 \mathrm{~A} \\
11 \mathrm{~B}\end{array}$ & $\begin{array}{l}\text { Silicious-car- } \\
\text { bon-bearing rock } \\
\text { with mica }\end{array}$ & Massive & $\begin{array}{l}\text { Mica }-80 \% \text {, } \\
\text { Carbon-bearing substance }-14 \% \text {, } \\
\text { ore mineral }-1 \%\end{array}$ & $\begin{array}{l}\text { Single grains of ore } \\
\text { mineral }\end{array}$ & $3.2 \cdot 10^{-4}$ & $\begin{array}{l}0.36 \\
0.24 \\
700\end{array}$ \\
\hline $\begin{array}{l}12 \mathrm{~A} \\
12 \mathrm{~B}\end{array}$ & Talc-actinolite & Massive & $\begin{array}{l}\text { Actinolite - } 70 \% \text {, } \\
\text { talc }-15 \% \text {, } \\
\text { phlogopite -13\%, } \\
\text { ore mineral (about 1-2 \%) }\end{array}$ & $\begin{array}{l}\text { Single grains of ore } \\
\text { mineral are distribut- } \\
\text { ed unevenly. }\end{array}$ & $1.4 \cdot 10^{-4}$ & $\begin{array}{l}90000 \\
17000\end{array}$ \\
\hline $\begin{array}{l}13 A \\
13 B\end{array}$ & Glimmerite & Schistous & Brown-colored mica - 100 \%, & $\begin{array}{l}\text { Ore mineral } \\
\text { is not identified }\end{array}$ & $2.0 \cdot 10^{-4}$ & $\begin{array}{l}50000 \\
30000\end{array}$ \\
\hline
\end{tabular}




\begin{tabular}{|c|c|c|c|c|c|c|}
\hline $\begin{array}{l}\text { Sample } \\
\text { number }\end{array}$ & Rock & Texture & Mineral composition & Peculiar properties & $\begin{array}{l}\text { Magnetic } \\
\text { susceptibility, } \\
\text { SI units }\end{array}$ & $\begin{array}{c}\text { Electrical } \\
\text { resistivity, } \\
\text { MOhm }\end{array}$ \\
\hline $\begin{array}{l}14 \mathrm{~A} \\
14 \mathrm{~B}\end{array}$ & Amphibolite & Massive & $\begin{array}{l}\text { Plagioclase }-40 \% \text {, } \\
\text { amphibole }-45 \% \text {, } \\
\text { mica }-5 \%\end{array}$ & $\begin{array}{l}\text { Single inclusions } \\
\text { of ore mineral are } \\
\text { noted. }\end{array}$ & $3.2 \cdot 10^{-4}$ & $\begin{array}{l}2000 \\
1750\end{array}$ \\
\hline $\begin{array}{l}15 A \\
15 B\end{array}$ & $\begin{array}{l}\text { Quartz-mica } \\
\text { schist }\end{array}$ & Schistous & $\begin{array}{l}\text { Mica }-80 \% \\
\text { quartz }-15 \%\end{array}$ & $\begin{array}{l}\text { Ore mineral } \\
\text { is not identified }\end{array}$ & $4.0 \cdot 10^{-4}$ & $\begin{array}{l}300000 \\
400000\end{array}$ \\
\hline $\begin{array}{l}16 \mathrm{~A} \\
16 \mathrm{~B}\end{array}$ & Serpentinite & $\begin{array}{l}\text { Massive, } \\
\text { spotted }\end{array}$ & $\begin{array}{l}\text { Serpentine }-96 \% \text {, ore } \\
\text { mineral }-4 \%\end{array}$ & $\begin{array}{l}\text { Ore mineral (vein- } \\
\text { lets) is unevenly } \\
\text { distributed }\end{array}$ & $2.8 \cdot 10^{-4}$ & $\begin{array}{c}310 \\
360 \\
2400 \\
3500\end{array}$ \\
\hline $\begin{array}{l}17 \mathrm{~A} \\
17 \mathrm{~B}\end{array}$ & Serpentinite & Massive & $\begin{array}{l}\text { Serpentine }-90 \% \text {, } \\
\text { ore mineral - } 10 \%\end{array}$ & $\begin{array}{l}\text { Ore mineral is dis- } \\
\text { tributed unevenly }\end{array}$ & $2.5 \cdot 10^{-3}$ & $\begin{array}{l}25000 \\
18000\end{array}$ \\
\hline $\begin{array}{l}18 \mathrm{~A} \\
18 \mathrm{~B}\end{array}$ & Diorite & $\begin{array}{l}\text { Massive, } \\
\text { knotty }\end{array}$ & $\begin{array}{l}\text { Amphibole }-35 \% \text {, plagioclase - } \\
45 \% \text {, mica }-15 \% \text {, quartz }-5 \%\end{array}$ & $\begin{array}{l}\text { Ore mineral } \\
\text { is not identified }\end{array}$ & $1.5 \cdot 10^{-4}$ & $\begin{array}{l}1600 \\
2400\end{array}$ \\
\hline $\begin{array}{l}19 A \\
19 B\end{array}$ & Quartz rock & Massive & Quartz - $100 \%$ & $\begin{array}{l}\text { Ore mineral } \\
\text { is not identified }\end{array}$ & 0 & $\begin{array}{c}50000 \\
400000\end{array}$ \\
\hline $\begin{array}{l}20 A \\
20 B\end{array}$ & Chlorite-talc & Schistous & $\begin{array}{l}\text { Talc }-75 \% \text {, chlorite }-20 \% \text {, ore } \\
\text { mineral (less than } 5 \% \text { ) }\end{array}$ & $\begin{array}{l}\text { Ore mineral (silt) is } \\
\text { evenly distributed }\end{array}$ & $2.0 \cdot 10^{-4}$ & $\begin{array}{c}9000 \\
320000\end{array}$ \\
\hline $\begin{array}{l}21 \mathrm{~A} \\
21 \mathrm{~B}\end{array}$ & $\begin{array}{l}\text { Glimmerite } \\
\text { with fluorite }\end{array}$ & Schistous & Mica - $75 \%$, fluorite- $25 \%$ & $\begin{array}{l}\text { Ore mineral } \\
\text { is not identified }\end{array}$ & $1.7 \cdot 10^{-4}$ & $\begin{array}{l}150000 \\
100000\end{array}$ \\
\hline $\begin{array}{l}22 \mathrm{~A} \\
22 \mathrm{~B}\end{array}$ & Serpentinite & Massive & $\begin{array}{l}\text { Serpentine }-95 \% \text {, } \\
\text { talc }-4 \% \text {, } \\
\text { ore mineral - } 1 \%\end{array}$ & $\begin{array}{l}\text { Ore mineral (single } \\
\text { grains) is distributed } \\
\text { unevenly }\end{array}$ & $6.5 \cdot 10^{-4}$ & $\begin{array}{c}320000 \\
20000\end{array}$ \\
\hline $\begin{array}{l}23 \mathrm{~A} \\
23 \mathrm{~B}\end{array}$ & $\begin{array}{l}\text { Talcose ser- } \\
\text { pentinite }\end{array}$ & Massive & $\begin{array}{l}\text { Talc }-45 \% \text {, } \\
\text { Serpentine - } 40 \% \text {, } \\
\text { ore mineral - } 5 \%\end{array}$ & $\begin{array}{l}\text { Ore mineral (single } \\
\text { grains) is distributed } \\
\text { extremely unevenly }\end{array}$ & $1.5 \cdot 10^{-4}$ & $\begin{array}{l}600000 \\
80000\end{array}$ \\
\hline $\begin{array}{l}24 A \\
24 B\end{array}$ & $\begin{array}{l}\text { Dolerine with } \\
\text { phlogopite }\end{array}$ & Schistous & $\begin{array}{l}\text { Talc }-65 \%, \text { mica }-34 \% \text {, } \\
\text { ore mineral }-1 \%\end{array}$ & $\begin{array}{l}\text { Ore mineral in the } \\
\text { form of small grains }\end{array}$ & $2.2 \cdot 10^{-4}$ & $\begin{array}{l}170000 \\
100000\end{array}$ \\
\hline $\begin{array}{l}25 A \\
25 B\end{array}$ & Diorite & Schistous & $\begin{array}{l}\text { Amphibole } 5-7 \% \text {, feldspar }-65 \% \text {, } \\
\text { mica }-25-30 \%\end{array}$ & $\begin{array}{l}\text { Ore mineral } \\
\text { is not identified }\end{array}$ & $1.3 \cdot 10^{-4}$ & $\begin{array}{l}300000 \\
200000\end{array}$ \\
\hline $\begin{array}{l}26 \mathrm{~A} \\
26 \mathrm{~B}\end{array}$ & $\begin{array}{l}\text { Talcose ser- } \\
\text { pentinite }\end{array}$ & Massive & $\begin{array}{l}\text { Serpentine }-80 \% \text {, talc }-15 \% \text {, } \\
\text { ore mineral (about } 5 \% \text { ) }\end{array}$ & $\begin{array}{l}\text { Ore mineral (bunch- } \\
\text { es) is distributed } \\
\text { very unevenly }\end{array}$ & $4.0 \cdot 10^{-4}$ & $\begin{array}{c}90000 \\
150000\end{array}$ \\
\hline $\begin{array}{l}27 \mathrm{~A} \\
27 \mathrm{~B}\end{array}$ & $\begin{array}{l}\text { Actinolite-chlorite } \\
\text { Schist }\end{array}$ & Massive & $\begin{array}{l}\text { Actinolite }-60 \% \text {, talc }-35 \% \text {, ore } \\
\text { mineral (about } 5 \% \text { ) }\end{array}$ & $\begin{array}{l}\text { Ore mineral (single } \\
\text { grains) is distributed } \\
\text { unevenly }\end{array}$ & $1.7 \cdot 10^{-4}$ & $\begin{array}{l}110 \\
115\end{array}$ \\
\hline $\begin{array}{l}28 \mathrm{~A} \\
28 \mathrm{~B}\end{array}$ & $\begin{array}{l}\text { Chlorite-talc-ac- } \\
\text { tinolite }\end{array}$ & Schistic & $\begin{array}{l}\text { Amphibole }-44 \% \text {, chlorite }-25 \\
\% \text {, talc }-30 \% \text {, ore mineral }-1 \%\end{array}$ & $\begin{array}{l}\text { Ore separation in the } \\
\text { form of fine grains }\end{array}$ & $2.3 \cdot 10^{-4}$ & $\begin{array}{c}32 \\
40 \\
2300 \\
2200\end{array}$ \\
\hline $\begin{array}{l}29 A \\
29 B\end{array}$ & Serpentinite & Knotty & $\begin{array}{l}\text { Serpentine }-80 \% \text {, talc }-15 \% \\
\text { ore mineral }(5 \%)\end{array}$ & $\begin{array}{l}\text { Ore mineral (fine } \\
\text { impregnation) is dis- } \\
\text { tributed along cracks } \\
\text { and occasionally }\end{array}$ & $1.7 \cdot 10^{-4}$ & $\begin{array}{l}4500 \\
4700\end{array}$ \\
\hline $\begin{array}{l}30 \mathrm{~A} \\
30 \mathrm{~B}\end{array}$ & $\begin{array}{l}\text { Serpentine-talc } \\
\text { rock }\end{array}$ & $\begin{array}{l}\text { Knotty, } \\
\text { eutaxic }\end{array}$ & $\begin{array}{l}\text { Serpentine - } 30 \% \text {, talc } 65 \% \text {, ore } \\
\text { mineral }(5 \%)\end{array}$ & $\begin{array}{l}\text { Ore mineral (single } \\
\text { grains) is distributed } \\
\text { extremely unevenly }\end{array}$ & $3.5 \cdot 10^{-4}$ & $\begin{array}{c}55000 \\
320000\end{array}$ \\
\hline
\end{tabular}

is $10^{-2} \ldots 10^{-1}$ SI units), ilmenite (magnetic susceptibility is $4 \ldots 25$ SI units) and titanite (less commonly magnetite). There are magnetite, ilmenite, and titanite in talc, chlorite and tremolite-actinolite schists, which affect the overall magnetic susceptibility of rocks. Mica complexes mainly consist of phlogopite (magnetic susceptibility is $20 \cdot 10^{-5}$ SI units), but chromite, ilmenite, and titanite are rarely found in them. The content of accessory minerals in micas does not exceed two decimal places and three decimal places [15]. Sometimes fine-grained magnetite is found in apodiorite glimmerites, which increases the overall magnetic 


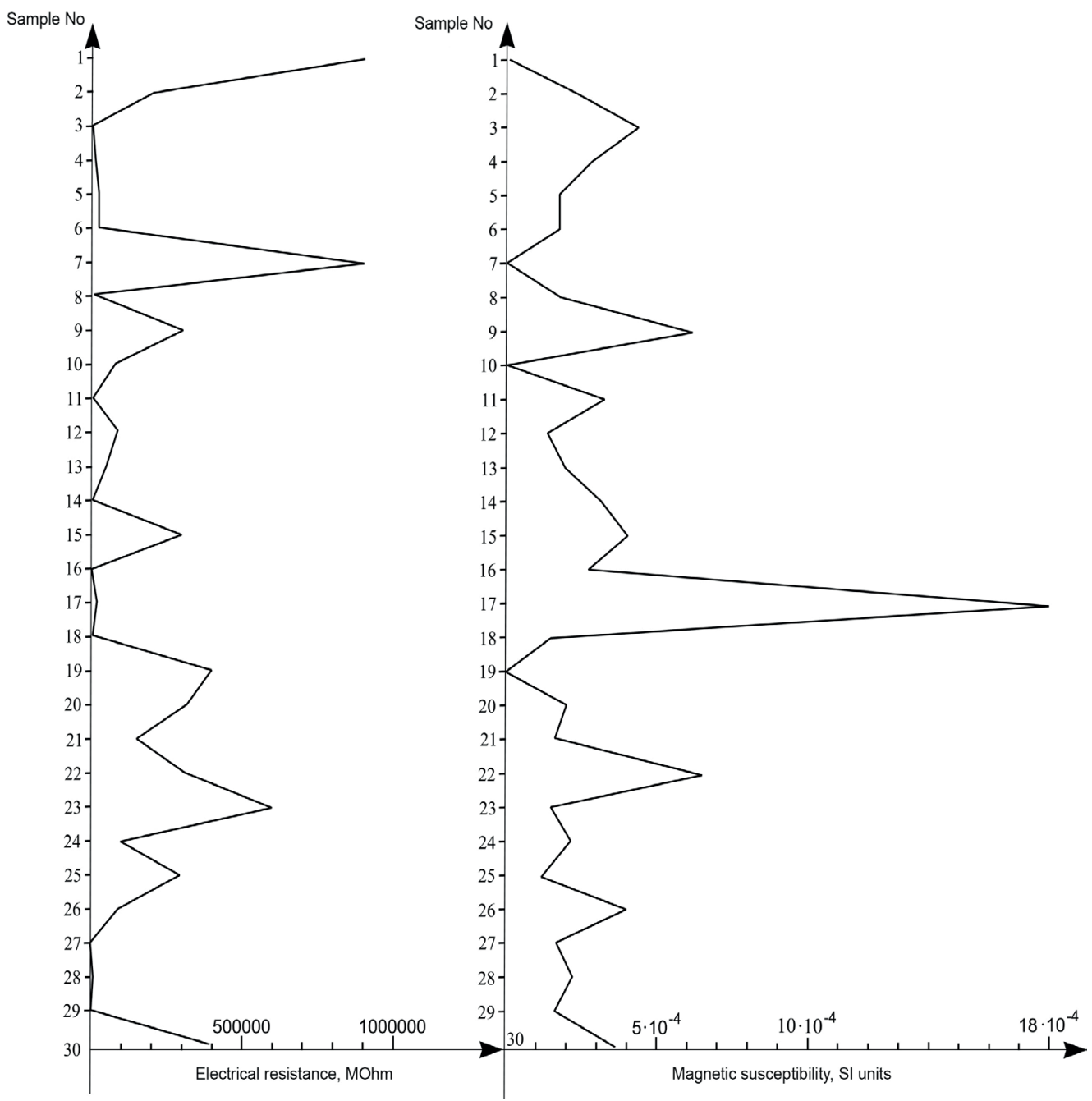

Figure 2. Values of electrical resistance and magnetic susceptibility for selected samples from the Mariinsky deposit.

Рисунок 2. Значения электросопротивления и магнитной восприимчивости на отобранных образцах с Мариинского месторождения.

susceptibility of these rocks. The magnitude of the magnetic susceptibility of quartz-plagioclase veins is below the measurement limit of the PIVM-M device ( $k<10^{-5}$ SI units) due to the absence of the main "magnetic minerals" (magnetite, pyrrhotite, ilmenite). The location of ore-bearing zones along the boundaries of the contacts of serpentinites with glimmerites makes it possible to identify zones of these contacts by magnetic susceptibility. Serpentinites have a greater magnetic susceptibility $\left(10^{-4} \ldots 10^{-3} \mathrm{SI}\right.$ units) than other rocks.

The works carried out by the authors in the mine of the Mariinsky emerald-beryllium deposit followed by laboratory studies showed that the main carrier rocks of beryllium mineralization (glimmerites and quartz-plagioclase veins) differ in magnetic susceptibility from other rocks of this deposit. Thus, the magnetic susceptibility of phlogopite schists ranges from 0.2 to $2.3 \cdot 10^{-4}$ SI units. The magnetic susceptibility of plagioclase-quartz veins is equal to zero. The host rocks (serpentinites), in turn, have a magnetic susceptibility $30 \cdot 10^{-4}$ SI units. The obtained values of apparent resistivity also show the difference between unproductive vein complexes and those containing the ore component (beryl). In addition, there is a dependence of the electrical resistance values of hyperbasites on the degree of metamorphism:

- peridotites slightly serpentinized - 1600 ... 2400 MOhm, sam. No 18;

- serpentinites $-3500 \ldots 25000 \mathrm{MOhm}$, sam. No 5, 16, 22;

- serpentinite-talc-carbonate rocks - $400 \ldots 450$ MOhm, sam. No 8;

- mica veins - 30000 ... $320000 \mathrm{MOhm}$, sam. No 13, 2.

According to the results of the work, it was found that mica veins are found only in hyperbasites of low-resistivity. It is obvious that the decrease in electrical resistance is due to a complex of metamorphic processes. Mica veins are distinguished among host rocks by high electrical resistance, which is caused by their composition - these are schists consisting mainly of phlogopite with mica scales along schistosity. According to the data of parametric measurements of samples in early studies [2], the average specific electrical resistance of mica veins is $70000 \mathrm{Ohm} \cdot \mathrm{m}$, which is significantly higher than the electrical resistance of host rocks. A similar situation is observed in our research.

If we jointly construct graphs (Fig. 2) of magnetic susceptibility and electrical resistance for various types of rocks found in the Mariinsky deposit, then it can be noted that the separation of mica veins only according to magnetic susceptibility is impossible due to a large number of nonmagnetic rocks. The separation of productive mica veins only according to the electrical resistiv- 
ity data is also not possible due to the presence of rocks of the same electrical resistivity. However, the use of these two methods at the same time when setting certain studied parameters makes it possible to create equipment for the express method of inspection and selection of promising ore zones (complexes).

Conclusions

The method proposed by the authors is based on difference in magnitude of the magnetic susceptibility and electrical resistance in the ore and ore-free sites. For each of the parameters studied, it is impossible to indicate unequivocally about the degree of mineralization; however, their complex use and interpretation allow us to identify signs by which ore zones can be distinguished in the field.

The use of this express method at the site (in mine workings) will allow for prompt determination of the location of serpentinite bodies and talc schists, in contact of which micaceous complexes productive for beryllium mineralization are often found.

This method (with a large set of statistical data) will allow us to confidently distinguish productive apohyperbasite glimmerites from unproductive apodiorite and other micaceous complexes at the Mariinsky deposit.

Acknowledgements

This work was supported partly by the Ural Branch of the Russian Academy of Sciences Program called "Development of petrophysical methods for studying rocks and ores in order to study the geological structure of deposits and improve their prospecting and exploration methods" (Project 18-5-5-52) and the state program called "Reconstruction of the formation conditions complexes of the Ural-Mongolian fold belt and associated mineralization "(State number AAAA-A18-118052590033-3).

\section{REFERENCES}

1. Shestakov V. V. 1987, Yaderno-geofizicheskiy ekspress-analiz transportiruyemykh rud i resursosberegayushchiye tekhnologii [Nuclear and geophysical express analysis of transported ores and resource-recovery technologies]. Sverdlovsk, $110 \mathrm{p}$.

2. 2008, Otsenka resursnogo potentsiala izumrudonosnykh formatsiy Rossii na osnove razrabotki sovremennykh prognozno-poiskovykh kompleksov: sbornik statey po otsenke mestorozhdeniy perspektivnykh dragotsennykh kamney [Evaluation of the resource potential of emerald-bearing formations of Russia based on the development of modern expected and prospecting complexes: collected papers on the evaluation of deposits of promising gems]. Moscow, $246 \mathrm{p}$.

3. Everett M. E. 2013, Near-Surface Applied Geophysics. Cambridge: Cambridge University Press, 442 p.

4. Hao J., Gu Z., Zhou J. 1997, Anisotropy of magnetic susceptibility of rocks induced by experimental deformation. Annals of Geophysics, vol. 40, no. 2, pp. 455-462. https://doi.org/10.4401/ag-3923

5. Zhernakov V. I. 1998, Topaz-paragonite metasomatic complexes of the Mariinsky emerald deposit. In: Geology of metamorphic complexes. Ekaterinburg, pp. 94-101.

6. Zolotukhin F. F. 1996, Mariinskoye (Malyshevskoye) mestorozhdeniye izumruda, Sredniy Ural [Mariinskoye (Malyshevskoye) emerald deposit, the middle Urals]. Asbest; Ekaterinburg; Saint-Petersburg, $70 \mathrm{p}$.

7. Zhernakov V. I. 1982, Opredeleniye polozheniya izumrudnogo orudeneniya v metasomaticheskikh kolonkakh slyuditovogo tipa [Determination of the position of emerald mineralization in metasomatic columns of mica type]. Metasomatism and ore formation: Proceedings of the All-Russian conference (November 23-25) Kiev, pp. 24-25.

8. Hoover D. B., Williams B., Williams C., Mitchell C. 2008, Magnetic susceptibility, a better approach to defining garnets. The Journal of Gemmology, vol. 31, no. 3/4, pp. 91-103.

9. Grimley D. A., Wang J.-S., Liebert D. A., Dawson J. O. 2008, Soil magnetic susceptibility: a quantitative proxy of soil drainage for use in ecological restoration. Restoration Ecology, no. 16, pp. 657-667. https://doi.org/10.1111/j.1526-100X.2008.00479.x

10. Zhanxiang He, Yunxiang Liu, Xiaodong Suo, Dong Weibin. 2008, Application of Magnetic Prospecting in Recognition of Volcanic Reservoirs. Recorder (official publication of the Canadian Society of exploration geophysicists), vol. 33, no. 01, pp. 45-48.

11. Filatov V. V. 2008, Magnitorazvedka: magnitnaya vospriimchivost', indutsirovannaya i yestestvennaya ostatochnaya namagnichennosti [Magnetic survey: magnetic susceptibility, induced and natural residual magnetization]. Ekaterinburg, $236 \mathrm{p}$.

12. Amadu Casmed Charles, Gawu Simon K. Y, Abanyie K. Samuel. 2018, Experimental Study of Electrical Resistivity to Rock Fracture Intensity and Aperture Size. International Journal of Physics, vol. 6, no. 3, pp. 85-92. https://doi.org/10.12691/ijp-6-3-4

13. Permyakov M. E., Manchenko N. A., Duchkov A. D., Manakov A. Yu., Drobchik A. N., Manshtein A. K. 2017, Laboratory modeling and measurement of the electrical resistivity of hydrate-bearing sand samples. Russian Geology and Geophysics, vol. 58, pp. 642-649. https://doi. org/10.1016/j.rgg.2017.04.005

14. Bakhterev V. V. 2015, Regularities of changes in the electrical parameters of rock samples of hyperbasite massifs of the Urals at high temperatures. Izvestiya Vysshikh Uchebnykh Zavedeniy [Proceedings of Higher Schools], including the journal Geologiya i Razvedka [Geology and Exploration], no. 2, pp. 41-47. (In Russ.) https://doi.org/10.32454/0016-7762-2015-2-41-47

15. Laskovenkov A., Fand N., Zhernakov V. 1990, An Update on the Ural Emerald Mines. Gems \& Gemology, vol. 31, no. 2, pp. 106-113. 


\title{
Геосизические критерии выделения продуктивных слюдитовых жия Мариинского изумрудно-берилмиевого месторождения (Средний Ураи)
}

\author{
Михаил Петрович Попов ${ }^{1,2^{*}}$ \\ Олег Петрович Пелешко ${ }^{3, * *}$, \\ Евгения Анатольевна Баженова ${ }^{4, * *}$, \\ Виктор Сергеевич Иванченко ${ }^{4, * \star *}$, \\ Владимир Васильевич Бахтерев ${ }^{4, * * * * *}$
}

1Уральский государственный горный университет, Россия, Екатеринбург

${ }^{2}$ Институт геологии и геохимии им. А. Н. Заварицкого УрО РАН, Россия, Екатеринбург

${ }^{3} \mathrm{AO}$ «Мариинский рудник», Россия, Свердловская область, г. Асбест, пос. Малышева

${ }^{4}$ Институт геофизики им. Ю. П. Булашевича УрО РАН, Россия, Екатеринбург

\begin{abstract}
Актуальностью работы является разработка новых методов оперативного выделения (обнаружения) рудных тел непосредственно в подземном руднике месторождения. Измерения были проведены как на специально подготовленных образцах в форме кубиков одного размера, так и в условиях естественного заяегания.

Целью работы является изучение магнитной восприимчивости и электросопротивления основных вмещаюших пород и рудного компмекса (изумрудоносных слюдитов и кварц-плагиокиазовых жил с беримом) на самом известном уральском изумрудно-беримиевом месторождении - Мариинском.

Методология исследования: Аяя исследований магнитных свойств типовых пород и рудных тел Мариинского месторождения непосреАственно в подземном руднике использовался измеритель магнитной восприимчивости полевой ПИМВ-М с диапазоном измерения $1 \cdot 10^{-5} \ldots 1$ ед. СИ. Относительная погрешность измерения не превосходит $\pm 10 \%$ в Аиапазоне $10^{-4} \ldots 1$ ед. СИ. Измерение проводилось путем плотного прикиадывания плоской поверхности первичного преобразователя прибора к стенке забоя в Аитологически однородный участок с последуюшим измерением и записью полученного значения в полевой журнаи документации горных выработок. Аяя изучения электросопротивления были использованы стандартные образцы в форме кубиков размером $24 \times 24 \times 24$ мм, состав которых парамельно изучался под бинолупой МБС-10. Измерения проводились по трем осям, так как практически у всех образцов присутствует анизотропия. Аяя работы использовался тераомметр Е6-13А.

Результаты. Приведены Аанные по магнитной восприимчивости и электросопротивлению основных вмешающих пород и рудного комплекса (изумрудоносных слюдитов и кварц-плагиокиазовых жил с беримом) с Мариинского месторождения. Все данные согласованы с петрограсическими характеристиками пород.

Выводы. Показана принципиальная возможность создания новой экспресс-методики выделения продуктивных слюдитовых жил в скважинах и забоях по одновременному измерению магнитной восприимчивости и электросопротивления пород непосредственно в процессе $А$ оычных работ в подземном руднике.
\end{abstract}

КАючевые слова: Урал, магнитная восприимчивость, электросопротивление, сяюдиты, кварц-плагиокиазовые жимы, изумрудно-беримиевые месторождения, Урамьские изумрудные копи.

Работа выполнена частично при поддержке Программы УрО РАН «Разработка петробизических методов исследований горных пород и руд с иелью изучения геологического строения месторождений и совершенствования методов их поиска и разведки» (Проект 18-5-5-52) и государственной программы «Реконструкция условий формирования габбро-ультрабазитовых комплексов Урало-Монгольского складчатого пояса и связанного с ними оруденения» (Гос. номер AAAA-A18-118052590033-3).

\section{ЛИТЕРАТУРА}

1. Шестаков В. В. Ядерно-геофизический экспресс-анализ транспортируемых руд и ресурсосберегающие технологии. Свердловск: УНЦ AH CCCP, 1987. $110 \mathrm{c}$

2. Оценка ресурсного потенциала изумрудоносных формаций России на основе разработки современных прогнозно-поисковых комплексов: сборник статей по оценке месторождений перспективных драгоценных камней. М.: ФГУП «Центркварц», 2008.246 с.

3. Everett M. E. Near-Surface Applied Geophysics. Cambridge: Cambridge University Press, 2013. 442 p.

4. Hao J., Gu Z., Zhou J. Anisotropy of magnetic susceptibility of rocks induced by experimental deformation // Annals of Geophysics. 1997. Vol. 40, № 2. P. 455-462. https://doi.org/10.4401/ag-3923

5. Жернаков В. И. Топаз-парагонитовые метасоматические комплексы Мариинского месторождения изумруда //Геология метаморфических комплексов. Екатеринбург: УГГГА, 1998. С. 94-101.

6. Золотухин Ф. Ф. Мариинское (Малышевское) месторождение изумруда, Средний Урал. Асбест; Екатеринбург; СПб.: СПбГУ, 1996.70 с. 7. Жернаков В. И. Определение положения изумрудного оруденения в метасоматических колонках слюдитового типа // Метасоматизм и рудообразование: тез. докл. V Всерос. конф. (23-25 нояб.). Киев, 1982. С. 24-25.

8. Hoover D. B., Williams B., Williams C., Mitchell C. Magnetic susceptibility, a better approach to defining garnets // The Journal of Gemmology. 2008. Vol. 31, № 3/4. P. 91-103.

popovm1@yandex.ru

http://orcid.org/0000-0002-0527-8234

o.peleshko@ambercombine.ru

"*mbazenova_jena@mail.ru

https://orcid.org/0000-0002-2068-7140

vanchenko 05@mail.ru

http://orcid.org/0000-0002-1294-6050

ugv@bk.ru

http://orcid.org/0000-0002-1174-1301

46 Попов М. П. и др. Geophysical criteria for the separation of productive micaceous veins of the Mariinsky emerald-beryllium deposit (the Middle Urals) // Известия УГГУ. 2019. Вып. 1(53). C. 39-47. DOI 10.21440/2307-2091-2019-1-39-47 
9. Grimley D. A., Wang J.-S., Liebert D. A., Dawson J. O. Soil magnetic susceptibility: a quantitative proxy of soil drainage for use in ecological restoration // Restoration Ecology. 2008. № 16. P. 657-667. https://doi.org/10.1111/j.1526-100X.2008.00479.x

10. Zhanxiang He, Yunxiang Liu, Xiaodong Suo, Dong Weibin. Application of Magnetic Prospecting in Recognition of Volcanic Reservoirs // Recorder (official publication of the Canadian Society of exploration geophysicists). 2008. Vol. 33, № 01. P. 45-48.

11. Филатов В. В. Магниторазведка: магнитная восприимчивость, индуцированная и естественная остаточная намагниченности. Екатеринбург: Изд-во УГГУ, 2008. 236 с.

12. Amadu Casmed Charles, Gawu Simon K. Y, Abanyie K. Samuel. Experimental Study of Electrical Resistivity to Rock Fracture Intensity and Aperture Size // International Journal of Physics. 2018. Vol. 6, № 3. P. 85-92. https://doi.org/10.12691/ijp-6-3-4

13. Permyakov M. E., Manchenko N. A., Duchkov A. D., Manakov A. Yu., Drobchik A. N., Manshtein A. K. Laboratory modeling and measurement of the electrical resistivity of hydrate-bearing sand samples // Russian Geology and Geophysics. 2017. Vol. 58. Issue 5. P. 642-649. https://doi. org/10.1016/j.rgg.2017.04.005

14. Бахтерев В. В. Закономерности изменения электрических параметров образцов горных пород гипербазитовых массивов Урала при высоких температурах // Изв. вузов. Геология и разведка. 2015. № 2. С. 41-47. https://doi.org/10.32454/0016-7762-2015-2-41-47

15. Laskovenkov A., Fand N., Zhernakov V. An Update on the Ural Emerald Mines // Gems \& Gemology. 1990. Vol. 31, № 2. P. $106-113$.

Статья поступила в редакцию 13 ноября 2018 г. 